\title{
TITLE:
}

\section{Japanese human resource management from the viewpoint of incentive theory}

\section{AUTHOR(S):}

Itoh, Hideshi

\section{CITATION:}

Itoh, Hideshi. Japanese human resource management from the viewpoint of incentive theory. 京都大学経済学部Working Paper 1991, 13

ISSUE DATE:

1991-06

URL:

http://hdl.handle.net/2433/37908

RIGHT: 
JAPANESE HUMAN RESOURCE MANAGEMENT

FROM THE VIEWPOINT OF INCENTIVE THEORY

by

Hideshi Itoh

Faculty of Economics

Kyoto University

Faculty of Economics,

Kyoto University,

Kyoto, 606 JAPAN 
JAPANESE HUMAN RESOURCE MANAGEMENT

FROM THE VIEWPOINT OF INCENTIVE THEORY

by

Hideshi Itoh

Faculty of Economics

Kyoto University

June 1991 


\title{
JAPANESE HUMAN RESOURCE MANAGEMENT FROM THE VIEWPOINT OF INCENTIVE THEORY
}

\author{
BY \\ HIDESHI ITOH \\ Faculty of Economics \\ Kyoto University \\ Sakyō-ku, Kyoto 606-01, Japan \\ TEL: +81-75-753-3423, FAX: +81-75-751-1532 \\ BITNET: e52832@jpnkudpc.bitnet
}

June 1991

Forthcoming in Current Topics on the Japanese Economy, a special issue of Ricerche Economiche, edited by Masahiko Aoki and Giorgio Brunello. 


\begin{abstract}
This essay concerns the management of human resources in the stylized large Japanese firm. The emphasis is on issues of internal incentives, how the Japanese firm provides its employees with incentives to behave in harmony with goals of the firm. By drawing freely the insights from the growing literature on the economics of organizations (incentive theory), I attempt to explain economic rationale of some of the distinct features of Japanese management practices concerning pay and promotion systems.
\end{abstract}

JEL Classification Numbers: J41 


\title{
JAPANESE HUMAN RESOURCE MANAGEMENT FROM THE VIEWPOINT OF INCENTIVE THEORY
}

\author{
Hideshi ITOH \\ Faculty of Economics, Kyoto University
}

\section{Introduction*}

This essay concerns the management of human resources in the stylized large Japanese firm. The emphasis is on issues of internal incentives, how the Japanese firm provides its employees with incentives to behave in harmony with goals of the firm. ${ }^{1}$ The paper takes an economic approach: By drawing freely the insights from the growing literature on the economics of organizations (incentive theory), I attempt to explain economic rationale of some of the distinct features of Japanese human resource management practices, particularly on pay and promotion systems, as well as discuss possible reasons why they are different from the Western management practices. Of course, this does not imply that I intend to refute other paradigms such as those by sociologists, anthropologists, or historians: The economic approach is but one of many alternative ways to look at the Japanese management practices closely.

Presenting an exhaustive survey of the economic literature on Japanese firms is not the purpose of the paper. There are large bodies of comparative empirical studies that attempt to "demystify" Japanese management, identifying what distinguish the Japanese firm from its Western counterpart. Today's informed readers probably know that what is unique in Japan is a much more subtle question than popular writings have suggested. In Section 2, I briefly review some stylized facts about the Japanese human resource management, by referring to the recent empirical research. However, my aim throughout the paper is not to contribute to

* The author would like to thank Masahiko Aoki, Banri Asanuma, Osamu Hayashida, Hiroyuki Itami, John McMillan, Tsuyoshi Namikawa, Masuyuki Nishijima, Isao Ohashi, Toshiaki Tachibanaki, and Yuji Yumoto for helpful comments and discussions, and Akiko Yamazaki for editorial assistance. Financial support from the Japan Economic Research Foundation is gratefully acknowledged.

1 For issues on training and human capital, see the paper by Kato in the same volume. 
our further understanding of what is unique and what is not in Japanese firms. I basically take the characteristics summarized there for granted, and focus on their causes and economic rationality.

In Section 3, I discuss implications from the distinct characteristics of work organization structures of the Japanese firm for incentive issues. One of the main messages of the paper is that the reward structures of the Japanese firm are designed so as to alleviate various incentive problems associated with its work organization structures. Its differences in pay, promotions, and employment relations from the Western firm can also be attributed to the differences in work organization. I discuss some possible reasons why work organization structures are different between Japan and the West, but the discussion is highly incomplete because of the very preliminary stage of economic studies of organization structures.

The premise of the paper is the following: It is substantial lifetime pay differences stemming from different rates of promotions that motivate employees in the Japanese firm. Unfortunately, the empirical research testing this hypothesis is scarce. In Sections 4 to 6 , I thus focus on its theoretical justification and implications. Section 4 concerns the lack of pay for performance. The hypothesis implies that Japanese employees are not rewarded immediately and transiently after some (objective or subjective) measures of individual performance become available. Again, no empirical research is available, yet the recent development in the principal-agent paradigm provides some illuminating logic leading to such a feature, in particular, in the Japanese firm given its organization structures.

If pay for performance is absent in the short run, incentives must be provided for employees over their career, and to do so, long-term attachment between employers and employees is necessary. In Section 5, I discuss the nature of long-term relationships in Japan. My standpoint there is that it is structures and practices adopted by the Japanese firm which are responsible for the strong degree of employer-employee attachment over long periods.

Section 6 then concerns promotion schemes-reward attached to discrete "hierarchical ranks." I discuss several economic theories that explain why pay is attached to discrete ranks rather than individuals, and their implications for the promotion patterns characterizing the Japanese management practices, wide career and slow promotions. Section 7 is concluding remarks. 


\section{Stylized Facts}

The purpose of this section is to summarize some of the representative features of the human resource management practices of the stylized Japanese firm, in a comparative perspective to the Western firm. The summary here is brief and not intended to be complete: in particular, few supporting data will be shown. Aoki (1988), Hashimoto (1989), Koike (1988), and Lincoln and McBride (1987) offer more extensive surveys of the empirical studies, and detailed description and supporting data for the characteristics presented below. ${ }^{2}$

I have chosen to review the following topics: long-term employment relationships; compensation policies; promotion scheme; and work organization. Note that not all of Japanese firms or their employees share the features summarized below. My major focus is on regular male (both blue-collar and while-collar) workers of large private companies in Japan. ${ }^{3}$

FACT 1: Long-term employment relationships are more prevalent in Japan.

Long-term employment relationships are common not only in Japan but also in many Western countries. However, careful empirical studies seem to show that this feature is more prevalent in Japan: For example, an average worker in Japan stays longer with the same employer than an average worker in the U.S. does, and the former does not change jobs as often as the latter (Hashimoto and Raisian, 1985). Whittaker (1990)'s comparison between Japan and Britain shows that a greater proportion of Japanese workers has "long tenure" than British workers. Koike (1988) and OECD Employment Outlook (1984) contain similar results in comparison with other European workers as well.

The durable attachment of a worker to an employer occurs when the employer does not fire the worker and when the worker does not leave the firm. The first of these two conditions is known as "lifetime" employment: Except for extreme situations, the firm does not fire workers (until mandatory retirement, of course). ${ }^{4}$ The lifetime employment thus only binds the

${ }^{2}$ I have attempted to choose English references whenever available. However, I apologize to those readers who do not have Japanese language proficiency for sometimes (inevitably) referring to the literature written in Japanese.

3 Of course, this does not imply that medium/small firms or temporary/female workers are unimportant in the Japanese economy.

4 The Japanese firm usually resorts to shorter work hours, work sharing, and transfers, prior to firing. 
employer. Note however that this is not a contractual state: no explicit clause regarding this policy is found in the employment contract. In fact, Japanese labor law prohibits the contracts covering more than one year, and the usual practice is not to specify the employment period. Thus, the enforcement of the no-firing policy in Japan must somehow rely on non-contractual, implicit mechanisms such as reputation, which make the policy self-enforcing. ${ }^{5}$

The second condition for long-term employment relations, that Japanese workers do not separate from their employers in mid-career as often as workers in Western countries do, depends on the competitiveness of the external labor market. It is determined partly by exogenous factors and partly by endogenous factors such as structures and practices of firms. The discussion in Section 5 emphasizes the latter factors.

FACT 2: (a) Not only white-collar but also blue-collar workers are paid monthly salary and biannual bonuses; (b) Salary rises at regular intervals (usually every one to two years), and also at the time of promotion to higher hierarchical "ranks," on the basis of age and tenure (and merit assessments, particularly for the latter); (c) Wages are not attached to particular jobs, i.e., ranks are only loosely associated with specific job classifications.

Word "rank" in Fact 2 is worth clarifying. There are two kinds of discrete hierarchical ranks which I call vertical ranks and horizontal ranks. ${ }^{6}$ The former are associated with hierarchical titles (yakushoku) such as section chief, department head, and so on, and hence promotion to a higher vertical rank (shöshin) implies changes in authority and/or responsibility. On the other hand, the latter horizontal ranks are artificially created grades (kyü or shikaku) which are used for differential treatment of individuals in terms of status and/or pay only. Promotion to a higher rank in this sense (shōky $\bar{u}$ or shōkaku) implies no essential change in authority, responsibility, or jobs performed. These two sorts of ranks are interrelated to some degree since a hierarchical job title often has a specific grade as a prerequisite: promotion to a higher vertical rank may not be possible before a particular horizontal rank is reached.

Figure a illustrates the stylized pay scheme in Japan. A new employee is first assigned to

5 Despite this contractual incompleteness, however, judicial mechanisms sometimes enforce the lifetime employment policy in Japan. The Supreme Court has often ruled against firing decisions by firms unless they are sufficiently reasonable (Tsuchida, 1989).

6 These roughly correspond to "vertical hierarchies" and "horizontal hierarchies" in Stiglitz (1975), respectively. Aoki's (1988) "ranking hierarchy" is more associated with the latter, horizontal one. 
the lowest rank (Rank 1 in the figure), and is paid his salary which is attached to that rank. His salary increases regularly with tenure or age, along the curve. The pay raise also depends on merit assessment, and that is why each curve in the figure has some breadth: workers with the same tenure and age possibly receive different wages according to their merit ratings. The slope of each curve becomes less flat as the worker's age and tenure increase. At some point in his career, he is promoted to a higher rank (Rank 2) with the steeper wage-seniority curve, based on seniority and merit assessment. After he stays with that rank and receives regular pay raise according to the curve, he may be promoted to the next level (Rank 3), and this career development continues. Fact 2 is mainly concerning each wage-seniority curve. Promotion is the subject of Fact 3 below.

\section{[Insert Figure a about here.]}

Koike (1988) claims that many of the features in Fact 2 are common in white-collar workers in a number of Western countries, while only in Japan these features extend to production workers: the uniqueness of the Japanese firm is in its "white-collarization" of blue-collar workers. Ishida (1990) argues, based mainly on the comparison with British workers, that wages contingent on merit ratings are the most distinct characteristics of the pay system for Japanese production workers, which contrast with wages attached to jobs for production workers in the West. Several systematic empirical studies show that many of these characteristics are more prevalent in Japan. Hashimoto and Raisian (1985) find that (i) wages typically rise more rapidly with tenure for Japanese workers than for American workers; (ii) firm-specific experience (tenure) has a greater effect than general experience (total years of work experience) in Japan while the pattern is reversed in the United States. Kalleberg and Lincoln (1988) find that personal characteristics such as age, tenure, and marital status are important determinants of earnings for Japanese production workers while job characteristics play a greater role for American workers. In accordance with this last evidence, Ono (1989) argues that much of the positive slope of wage-seniority curves reflects the firm's intention to guarantee living expenses of workers.

There is no systematic research that attempts to measure the effect of merit assessments on salary increases in Japan. However, casual observation seems to indicate that the salary 
increase upon promotion is much more important than annual regular pay raise. Fujimura (1989), although the data are old (1966), reports that for most employees (about $80 \%$ for firms with more than 5,000 employees, $65 \%$ for firms with 1,000 to 4,999 employees) the difference between the highest and the lowest regular salary increases is within $5 \%$ range. Tachibanaki $(1987,1988)$, using the 1975 survey data on Social Stratification and Mobility in Japan, find that the hierarchical (vertical) ranks have the most important influence on. earnings differentials.

Other distinct features of compensation practices in the Japanese firm are biannual bonuses and lump-sum payment at the time of separation. What role the bonus system plays in Japan is a question that has frequently been discussed and examined by economists: The bonus may be a worker's share of returns to firm-specific human capital (Hashimoto, 1979), a sort of profit sharing mechanism stabilizing employment (Freeman and Weitzman, 1987) or providing effort incentives for the worker (Ohashi, 1989; Okuno, 1984). Aoki (1988) alerts us by noting that much of the bonus payment depends on merit assessments, more than basic salary contractually specified does. Aoki also notes that the separation payment typically rises sharply with tenure and depends on the reason of separation (private or company reasons).

FACT 3: (a) Workers in the Japanese firm tend to experience a wider range of closely related jobs than those in the Western firm; (b) The promotion pattern in Japan is a late selection approach, that is, the majority are not differentiated from their cohort until 10 to 15 years of tenure, and then only a minority is selected to go on to upper management positions.

Koike (1988) argues that (a) and (b) are two of the features that differentiate the human resource management of the Japanese firm from that of its Western counterpart. Unfortunately, there is not much systematic evidence. Koike (1988) offers some evidence of (a), while I know no comparative study of promotion speed. Rosenbaum (1979) observes patterns of early selections of "stars" in personnel date of a large firm in the United States. According to his data, 2 of 671 newly hired employees in $1962(0.3 \%)$ attained the highest position after 13 years of tenure. The personnel data of a large oil company in the United States in Forbes (1987) show that the ratio is $2 \%$ ( 4 of 180 reached the highest position after 11 years of tenure). On the other hand, Hanada (1989) offers career trees of 5 Japanese firms. The ratios of the employees in the same cohort who reached the highest rank after 15 years of tenure are $3 \%$, 
$65 \%, 74 \%, 81 \%$, and 100\%: Except for one firm, property (b) is evident. ${ }^{7}$ For other evidence on (b), see Pucik (1985) and papers in Koike (1991). ${ }^{8}$

Although seniority is still an important determinant of promotion decisions, merit ratings appear no less important. ${ }^{9}$ In the long run, substantial pay differences among workers with the same experience and education seem to emerge, which mainly originate from different promotion rates. Weiss $(1984,1988)$ find such a pattern in large Japanese manufacturers and argue that its motivational effect is a "reality" of Japanese productivity. One comparative study of large earnings data in Japan and the United States, Kalleberg and Lincoln (1988), finds that promotion expectations of workers are positively and strongly related to their earnings in Japan, though no such relation is found in American data.

FACT 4: (a) Job demarcation in work organization of the Japanese firm is more ambiguous and fluid; (b) More de facto responsibility is delegated to lower tiers of hierarchy in Japan.

The first feature is somehow summarized as follows. The Japanese firm tends not to use detailed job classifications nor to offer clear job description to each individual worker. Jobs are assigned to a group of workers who closely collaborate to perform them, via mutual help and information sharing. A group leader often has to some degree discretion over job assignment within the group. Workers perform multiple tasks via intragroup job rotation. Concerning the second feature, what is delegated may be a task to cope with emergency (Koike, 1988), coordination among workshops (Aoki, 1988), or production decisions such as scheduling and quality control (Cole, 1989; Monden, 1983).

There is ample anecdotal, case study evidence on these features, and even quantitative evidence based on systematic data exists, which mostly accord with the description given

7 However, his data also show that even though many individuals reach the highest position among them after 15 years, there is nonnegligible diversity (a few years) in their speed. In addition, Both Rosenbaum and Hanada find that employees promoted in the earliest period have much better chance of being further promoted than those not promoted in the earliest period.

8 Note that because of the nature of personnel data, most of the empirical literature mentioned here looks at career development during the high growth period in Japan, through 1960 s to $1970 \mathrm{~s}$. It is often said that Japanese labor practices are now changing, toward faster promotion, less dependence on seniority, and so on. I do not discuss this issue in the paper because of the lack of enough systematic, quantitative evidence at this time.

9 For example, the empirical study by Tachibanaki (1988) finds that seniority is important, but not a necessary condition, for promotion. 
above (Lincoln, et al., 1986; for other quantitative studies, see the survey by Lincoln and McBride).

\section{Work Organization Structures}

Because the focus of the paper is on internal incentives, I mostly take the characteristics of organization structures as given in my argument. Theoretical comparative analyses of different organization and information structures, with reference to Japanese work organization, are found in Aoki $(1986,1988,1990)$ and Itoh $(1987,1988)$. These papers take the team theoretic approach, assuming away incentive problems, and identify several environmental factors that affect the choice of organization structures: The Japanese type work organization with the properties mentioned in the previous section (Fact 4) is more effective as scale economies are less important, environmental changes are continual but not too drastic, or workers have sufficiently high learning capabilities. The results suggest possible explanations of the differences in work organization between Japan and the West. For example, there may be reasons in Japan that discount the importance of scale economies, such as the smaller domestic markets than those in the West and high land prices and the scarcity of land supply which raise inventory costs more in Japan and hence discourage high buffer inventories.

There is some preliminary theoretical research on organization structures from incentive viewpoints as well. Prendergast (1990b) studies delegation of responsibilities: He shows that managers may have an incentive to exert too much authority over their subordinates to improve own career prospects. He then shows that the problem is mitigated when the labor market is non-competitive, e.g., because firms collude in hiring. Itoh (1991a, b) show that work organization with ambiguous job demarcation may be preferred by the employer from a purely incentive reason: having workers engage in several activities make worker motivation keep high even though each task is monotonous and boring and hence they may free ride on others' help. ${ }^{10}$ This result depends on costs of workers' doing multiple tasks. Sometimes it is too costly to force workers to exert effort to an additional task quite different from his other tasks. In fact, Holmstrom and Milgrom (1990b) present the opposite case in which it is always optimal for

\footnotetext{
10 Monden (1983) regards this effect as one of the advantages of regular job rotation in the Toyota production system.
} 
the firm to make a worker specialize in a set of similar activities in terms of the measurability of performance, because such a job design reduces the distortion in how the worker allocates his attention among activities. Tirole (1986) argues that job rotation across work groups can discourage coalitional behavior detrimental to the organization, such as manipulation of information by supervisors while Itoh $(1990,1991 \mathrm{~b})$ argue that job rotation within work teams facilitates mutual monitoring and sanctioning among members, and the resulting cooperation among workers benefits the employer by reducing incentive costs.

Although these studies suggest that the optimal organization structures be determined partly by incentive considerations, they are still preliminary, and hence in this paper I mostly consider one direction, from structures to incentives.

The differences in work organization structures provide the following implications on incentive issues:

1. The Japanese firm suffers from the lack of objective individual performance measures of production workers, and thus relies on subjective performance measures more than the Western firm.

2. Cooperation among workers in performing tasks is more important in the Japanese firm because its structure is highly dependent on their lateral interactions.

3. The Japanese firm counts more on effort and capability at lower levels in hierarchy (via more extensive delegation) than the Western firm.

These claims being given, I analyze the reward system (compensation and promotion) in the Japanese firm in the subsequent sections.

\section{Weak Link between Pay and Performance in the Short Run}

The summary in Section 2 indicates that compensation for an employee in the Japanese firm is, in the short run, not sensitive to any of his performance measures, whatever available there are. By the short run I mean such a short period that no selection decision for promotion is made. Then each employee is paid a fixed basic salary associated with his pay rank, with biannual bonuses and various allowances. The basic pay in general increases regularly every year while the major determinants of the amount of pay raise seem to be personal characteristics such as age, tenure, marital status, and so on (for quantitative evidence, see Kalleberg 
and Lincoln (1988)). Although the bonuses depend on corporate performance, in large firms the perceived connection between bonuses and individual performance will be weak since the corporate performance measures such as profits are too much aggregated to reflect individual effort. Merit assessment is said to be an important determinant of an employee's earnings, while it is more important in promotion decisions, and the incentive effect of the merit rating on bonuses and regular increases in basic wages appears to be limited.

The purpose of this section is to offer theoretical justification for this seemingly weak tie between pay and performance in the short run. Note that this observation may be valid in Western firms as well as in Japanese firms. Baker et al. (1988) point out this anomaly by referring to empirical evidence from American data. Because I do not know any comparative empirical research on the extent of this feature in various countries, no attempt to explain international differences is made here, except for some predictions.

I assume that some sources of information about individual performance, either objective or subjective measures, are available: If neither of objective measure nor subjective assessment is available, the lack of pay for individual performance is obvious. ${ }^{11}$ I however remind the readers that as I have argued in the preceding section, objective measures even for production workers are hard to obtain under the Japanese work organization. The main point argued here is that given the work organization practices of the Japanese firm, it is often in the interest of the firm not to reward workers immediately and transiently after their performance measures become available.

\subsection{The Tradeoff between Incentives and Risk Sharing}

The principal-agent paradigm has provided theoretical basis for rewarding individual contributions. The standard moral hazard model illuminates a tradeoff between incentives and risk sharing (or fairness, in the sense that one would not like his/her rewards to be affected by uncontrollable factors): ${ }^{12}$ Suppose that an employee is offered a fixed (time-based) salary

11 In addition, I implicitly assume that these measures are verifiable in courts, and hence employment contracts can be written such that pay is contingent on them. Otherwise, pay cannot be contingent on current performance because there is a hazard of employers reneging the contracts which contain such pay for performance clauses. Note that in such a case pay can still be contingent on past performance because it can be self-enforceable via reputation (see MacLeod and Malcomson (1989) for a formal model), and hence the problems discussed here are still valid.

12 See Hart and Holmstrom (1987) for a survey. 
the level of which is competitive and high enough for him to accept it. Such a pay scheme has an advantage that the income of the employee is not subject to exogenous risk, given that he is risk averse (or has limited wealth). However, he is going to work in the way he likes best, as long as he is not caught by the firm for not behaving appropriately. Implicit here is the assumption that there is a conflict in interests between the firm and the employee, stemming from costs or distastes to exert effort, incongruity in risk preferences, different information concerning tasks, and so on. To induce desirable behavior, the firm must design compensation sensitive to the employee's actions via use of objective performance measures such as the number of units produced, sales, divisional profits, and so on, and subjective measures such as merit ratings by supervisors. They are however quite noisy measures of the employee's effort and hence make his income less predictable, subject to the factors that he cannot control. The result is higher average pay, because the firm must compensate for the risk premium so as to keep him work for the firm.

The argument given above offers one explanation of the lack of performance-based pay: it is sometimes too costly in terms of risk sharing to provide incentives through immediate pay for performance. Suppose that the firm can force an employee to select at least some minimum level of effort. Inducing him to work a little bit harder than that level is not costly if the minimum level is modest (e.g., being present at his private office). However, if the minimum level is so high (e.g., because he works with others including his boss in a large room) that a small increase of effort from the lowest possible level is painful (i.e., his marginal disutility is large), there is a fixed cost of providing incentives to work harder due to risk bearing. Thus, if the minimum enforceable effort level is already high, the firm may not provide incentives via pay for performance, unless a substantially higher level of effort is required. The argument depends on the costs of monitoring inputs (effort) and outputs (performance). Since the latter costs are higher under the Japanese work practices such as ambiguous job contents and regular job rotation within groups, it is expected that the practice of paying production workers contingent on objective measures will be less widespread in Japan.

\subsection{Missing Incentives for Multi-Task Workers}

When a worker is assigned to several different tasks or his single task has several aspects that cannot be characterized by a single activity, the incentive problem has a new dimension: 
allocation of effort to various tasks/activities. A production worker may have to care about his production rate, quality, machine condition, conditions of other workers, and so on. A salesman may attend to his sales volume as well as his reputation among consumers in his territory. A division manager will have to attend to not only short-run earnings but also longterm growth of the division. Various members of organizations are also expected to perform some routine work and at once to respond flexibly to unanticipated contingencies as they arise.

Some tasks or dimensions are easier to measure than others. If a worker's compensation is contingent on the performance measures of such activities, his allocation of effort may be biased toward those activities in sacrifice of others that are not easily measured. The point is not that pay for performance does not motivate workers but that it sometimes motivates them too much toward some specific directions. Thus if crucial activities are not measurable, it may be in the employer's interest to offer a fixed salary, or at best to tie individual pay with a broader performance measure like profits, even if good personalized measures for specific, but less important actions are available. Recently, this result is formally obtained by Holmstrom and Milgrom (1990b).

This theory suggests at least two possible reasons why pay for performance, particularly for blue-collar workers, is not common in Japan (relative to other industrialized nations, although I am not aware of empirical evidence). First, Japan's status as a "late developer" forced Japanese firms to adapt to rapidly changing environments. As a result, workers' timely and flexibly responses to unforseen contingencies were likely to be more valuable to the firms than their routine, deterministic behavior toward specific directions. ${ }^{13}$ Second, as is mentioned in the previous subsection, job demarcation in the Japanese firm is ambiguous, and each of its production workers performs a wider range of jobs than more specialist-oriented workers in the Western firm. Then, we expect that compensation strongly tied with specific measures, even if they are available, may be discouraged in Japan.

\subsection{Subjective Merit Assessment and Side Trades}

The remaining explanation of the lack of pay for performance is associated with subjective measures. Performance in many jobs, particularly for white-collar workers, cannot be measured objectively. Subjective measures are then introduced. Aoki (1988) in fact claims that

13 There is empirical evidence that even today, managers of large Japanese firms perceive their environments more volatile than those of large American firms do (Kagono et al., 1985). 
the "importance of merit assessment...is one of the distinctive characteristics of the Japanese payment scheme and contrasts with that in the unionized A-firm, where managers have much less discretionary power over an individual's earnings, which instead depend on the job evaluation system (one single wage rate for one job) and the seniority rule." (p. 56). However, he also states: "The merit assessment has more weight in the promotion decision." "The relative weight placed on the assessment of individual assessment in pay determination within the same grade differs from one firm to another. The union usually demands egalitarian treatment, and some firms have only a single basic pay rate for each grade." (p. 55). Although no study of actual data concerning the effects of merit ratings on regular increases in basic pay (as well as on bonuses) exists, ${ }^{14}$ its incentive effect seems to be not so large in the short run as theory suggests.

In the rest of this section, I discuss possible problems of strong link between pay and merit ratings in the short run. The point is that supervisors/performance raters are also self-interested agents, and hence their incentives matter in the design of pay structures. ${ }^{15}$

The first problem is that pay for performance makes it possible for supervisors to abuse their positions so as to benefit themselves at the expense of their employer. To illustrate the problem, consider the following simple three-tier hierarchy of an employer, a supervisor, and two workers, drawn from Laffont (1990). Each risk averse worker $i(i=1,2)$ exerts effort. His individual production level $x_{i}$ is a random variable whose value is either $H$ (high) or $L$ (low) with $H>L$. The probability of $x_{i}=H$ is increasing in worker $i$ 's effort level. However, $x_{i}$ is not observable to the employer: The only objective measure verifiable to the employer is a broad measure of total profits $x=x_{1}+x_{2}$. The employer can hire a supervisor who can observe and report individual production levels, which can be interpreted as merit ratings. Suppose that compensation is fixed at the beginning of each year. Thus, the first-year compensation is constant, while the second-year compensation can be contingent on the first-year performance.

This is a variant of the moral hazard model of the two-tier hierarchy where the tradeoff between incentives and risk sharing is the point. If the supervisor were honest, the firm

14 Fujimura (1989) is one exception.

15 The extensive use of subjective measures also affects workers' incentives: They may allocate too much energy to influence their supervisor's ratings, in sacrifice of other productive activities (Milgrom, 1988; Milgrom and Roberts, 1988). This is a variant of the problem of allocational inefficiency discussed above, and hence is not pursued further in this section. 
would offer each worker pay for performance in which his next-year pay is higher when his individual production level is high than when it is low. However, such a pay structure creates opportunities of covert side trades between the supervisor and the workers: The supervisor can form a coalition with one of the worker at the expense of the other, or he can extract private benefits from each worker by threatening to favor the other. ${ }^{16}$

Note that this sort of manipulation by the supervisor becomes possible only when each worker's compensation is tied with his individual rating: Laffont shows that it is sometimes optimal not to use the personalized pay scheme dependent on the supervisor's report in favor of pay contingent only on broader, more general objective measures. The latter nonpersonalized pay structure has the shortcoming that the employer is not using valuable information possessed by the supervisor to provide incentives for workers. The cost of ignoring the information will be higher if individual ratings contain additional information, e.g., about workers' unknown abilities. It is therefore in the firm's interest not to abandon the supervisor's information completely but to use it after some intervals, e.g., for promotion decisions. The delayed use of the subjective information may recreate an opportunity for detrimental side trades as described above. However, the chance of a successful trade seems to be smaller because side trades are now more difficult to enforce: When the supervisor and a worker form a coalition, the former will demand some favor in exchange of the promise of a counter-favor (good rating). The strong link between pay and ratings makes it easy for the worker to know whether the promise was kept. However, when the rating is only used much later in his career, the feasibility of side trading will be limited..$^{17}$

According to Edwards (1979) who analyzed historical evolution of the organization control systems in the United States, the arbitrary power of foremen/supervisors and the resulting problems such as favoritism, idiosyncrasies, prejudice, and so on, were in fact observed in the early decades of the 20th Century. And the system was abandoned along with other systems to reach "bureaucratic control" systems that combine formal bureaucracy and organizational

\footnotetext{
16 A related problem also arises in a simpler case where there is only one worker. Tirole (1986) analyzes such a model to show that when the employer uses the supervisor's information to reward the worker, the supervisor acts as an advocate and conceals evidence that is unfavorable to the worker.

17 As Tirole (1986) notes, job rotation across divisions, factories, or offices that breaks the long-term attachment of a worker with a particular supervisor further restricts side transfers.
} 
commitment as rewards. ${ }^{18}$ On the other hand, close personal relations with bosses are still common in the Japanese firm. Yoshino (1968) emphasizes the prevalence of informal groups in Japanese corporate organization, and discusses adverse effects of the informal cliques that arise from common cohort, birthplace, or school ties on formal organization structures, employee morale, and decision making. Lincoln and Kalleberg (1990) offer quantitative evidence based on their systematic data that strong vertical ties (between workers and supervisors) are far more prevalent in factories in Japan than those in the United States. Note that these observations do not necessarily imply that collusive behavior detrimental to the organization is actually prevailing. Tirole (1986) argues that observed collusive behavior is only the tip of the iceberg, because organizations can anticipate and react to the possibility of coalitions to restrict their formation. Aoki (1988) observes in the Japanese firm several devices that are intended to mitigate the danger of unfair treatment by supervisors: formalization and standardization of assessment procedures by the personnel department; job rotations both at the supervisory and the subordinate level; monitoring by the personnel department via grievances; and the importance of reputation of supervisors among subordinates for the former's career. ${ }^{19}$

\subsection{Team Production and Supervisors' Career Concerns}

The other problem associated with subjective performance appraisals and pay for performance concerns the assessment of supervisors. Supervisors in general perform not only supervisory tasks but also productive tasks such as coordination, training, and so forth. Then they are judged, in part, by their subordinates' performance, because it contains valuable information about supervisors' effort or ability. Thus, when a supervisor's compensation depends on his report concerning his subordinates' performance, his incentives to report may be perversely affected.

For example, the supervisor tends to overstate team performance when the performance measure is not verifiable. He inclines to overgenerosity in reporting the quality of subordinates

18 Ishida (1990) observes the similar problems in British firms, including Japanese factories in Britain.

19 On the other hand, some organizational practices of the Japanese firm seem to encourage on/off-the-job interaction with supervisors as well as with co-workers. For example, job rotation within work groups facilitates mutual monitoring and inter-dependence, and hence creates opportunities for worker cooperation via side trades, which can be beneficial to the organization. See Itoh $(1990,1991 b)$. 
when he is responsible for education and training. He may work too much to cover the problems in his workplace. He possibly passes responsibility for poor team performance, once detected by the employer, on subordinates. He tends to give subordinates undifferentiated ratings, in particular, when grievance systems activate. I know no formal model deriving these effects nor empirical evidence from Japanese data. However, the implication is that it is sometimes in the interest of the employer not to reward supervisors contingent on their reports in the short run.

Because of these problems in transient pay for performance in the short run, the firm may be motivated to engage in long-term relationships with employees and to use promotions as an incentive device. The subsequent sections discuss this possibility. An alternative solution is to use dismissal as a discipline device. For example, the presence of involuntary unemployment makes mid-career separation costly for workers, and hence they can be motivated to work without pay for performance by termination-type contracts in which each worker is fired when detected shirking, and otherwise he is paid a fixed wage. ${ }^{20}$ This approach seems difficult to pursue in Japan because firing is costly as is discussed in Section 2. The implication is that Japan and the West may be located in quite different equilibria in labor markets, one with long-term relationships and the other with short-term termination contracts. ${ }^{21}$ Both equilibria may be characterized as the lack of immediate pay for performance, but the solution to this problem can be quite different from one another.

Before moving, let me remark on my argument in this section. Here I have not considered incentive effects promotions may have on workers: promotions as an incentive scheme are supposed to be a result from the lack of pay for performance. Note, however, that the reverse may be true: incentive effects from promotions may be a cause of the absence of pay for performance. Suppose that workers (as well as the internal or external labor market) do not know their ability. Then the market (in the case of internal labor market, the current employer) uses their current performance to update its beliefs about their ability and to determine their future compensation and promotions based on these updated beliefs. The workers are then concerned about the effects of their current performance on future career.

20 See MacLeod and Malcomson (1989) and Shapiro and Stiglitz (1984) for formal models.

21 See Okuno-Fujiwara (1987) for a formal model along this line. 
This implicit incentive effect, called career concerns, can complement the explicit incentives through pay for performance. Gibbons and Murphy (1990) show that pay schemes optimize total incentives, the mixture of the incentives from career concerns and those from pay for performance. Career concerns are strong when workers are young and have many potential promotion opportunities. For these workers, the link between pay and performance is weak. On the other hand, pay for performance is important for those whose career concerns are weak, e.g., because they are close to retirement. It is desirable to test this prediction using Japanese data. ${ }^{22}$

\section{Explaining Long-Term Employer-Employee Attachment}

The previous section offered several possible reasons why the Japanese firm does not adjust pay immediately and transiently after some objective or subjective performance measures of workers are obtained. If the transient pay for performance does not provide incentives, then what does? The answer seems to be promotions and the resulting substantial differences in lifetime earnings among workers in the Japanese firm, observed and emphasized by Tachibanaki $(1987,1988)$ and Weiss $(1984,1988)$. Obviously, these incentives are effective only under strong long-term attachment between employers and employees. How long-term employment relationships can be sustained in Japan is the question discussed in this section.

The long-term employment relationships in Japan have often been explained by some exogenous factors such as traditional Japanese values stressing groupism and loyalty, or the lack of the competitive labor markets for those who leave firms in mid-career in Japan. There is in fact some evidence consistent with the latter that Japanese management practices prevail more in low growth areas (with fewer outside opportunities) than in high growth areas (with active labor markets) in a given country. (See, for example, Trevor (1983) for evidence in Britain.) However, in this paper, I take the proposition that it is structures and practices adopted by the Japanese firm which are responsible for the strong degree of employer-employee attachment over long periods. ${ }^{23}$ From this view, the lack of an active labor market for mid-

${ }^{22}$ Casual observation seems to accord with the prediction: As a worker moves up ranks, his pay depends more on his performance measures.

23 For a systematic empirical study of work organization and attitudes in the United States and Japan from this perspective, see Lincoln and Kalleberg (1990). 
career job changers in Japan can be characterized as an equilibrium outcome different from the equilibrium outcome in the West.

The robust long-term attachment occurs either because it is in the employee's interest not to leave the current firm for a new employer in his mid-career, or because it is in the employer's interest not to hire former employees of other firms. The following two subsections deal with these two facets, respectively.

\subsection{A Barrier to Exit by Wages Increasing with Seniority}

An employee does not quit the current firm, even if he can find a new employer who is ready to offer a better term, because it is costly for him to do so. The most well-known cost is the loss of firm-specific human capital in which the worker invested. Several empirical studies show that tenure has a stronger effect on the slope of wage profiles in Japan than in the United States, and the resulting steeper wage profiles reduce labor turnover (Hashimoto and Raisian, 1985, 1989; Mincer and Higuchi, 1988). However, this result is also consistent with the agency theoretic explanation of upward sloping wage-tenure profiles initially presented by Lazear $(1979,1983)$ : To discourage mid-career separation (as well as provide effort incentives) firms pay workers compensation less than the value of his marginal product when they are young, and greater than his marginal product when old (see also Murphy (1986)).

I know no empirical study testing these two competing hypotheses by using Japanese data. ${ }^{24}$ There are however some empirical observations in Japan that are puzzles from the perspective of specific human capital theory. First, there is a compensation paid at the time of separation, the amount of which is increasing sharply with tenure, and is higher when the separation is for company reasons than when it is for private reasons. This practice significantly increases mobility costs. However, this amount cannot be explained by a sudden increase in specific skills.

More importantly, many personnel practices of the Japanese firm are easily explained if we assume that old workers receive compensation more than the value of their marginal product. First, there is mandatory retirement. Although now rare in the United States, it is still common among large firms in Japan (as well as in Canada, Britain, etc.). The wellknown explanation of mandatory retirement by Lazear (1979) relies on the feature of his model

${ }^{24}$ See Hutchens (1987), Krueger (1991), and Lazear and Moore (1986) for tests using the U.S. data. 
that old workers are paid more than their value, and hence a date at which the contract is terminated must be fixed in advance. Second, with upward sloping wage profiles with the feature as above, the firm has an incentive to fire old workers. In order to maintain the wage profiles (to discourage mid-career separation), the firm therefore has to invest in reputation. The lifetime employment policy can be interpreted as such an example. Third, this feature is also compatible with the practice of the Japanese firm that when layoffs are inevitable, senior workers are the ones who are laid off first. The Japanese firm attempts to avoid layoffs in order to maintain reputation sustaining upward sloping wage profiles. However, when cutting labor costs becomes unavoidable, it is in the firm's interest to lay off those who are overpaid relative to their productivity.

Under the theory of specific human capital, senior workers are compensated less than or equal to the value of their marginal product (Becker, 1975; Hashimoto, 1981). The reason is that because specific training is productive only in the current firm, the firm bears part of the cost and collects part of the return to specific training. The agency perspective can complement the specific human capital story in order to explain these features of the Japanese firm. Many empirical studies of the Japanese labor market simply assume away the agency hypothesis in favor of the theory of specific human capital ${ }^{25}$ to explain the finding that earnings increase with tenure. More rigorous tests of alternative hypotheses are required ${ }^{26}$

\subsection{Perverse Effects of Mid-Career Recruiting}

Altough no empirical test is available, ${ }^{27}$ there are several possible reasons why firms may be reluctant to hiring those who separate from other firms (except at the bottom of the rank). First, outsiders may not be as productive as insiders because of the accumulation of firmspecific human capital. An employer, when hiring a new employee, must start investing in specific training which is costly relative to those who have already acquired the specific skills,

25 Or the "living expenses guarantee hypothesis" by Ono (1989) mentioned in Section 2.

26 For example, Mincer and Higuchi (1988) do not pursue the agency hypothesis by attributing to "the traditional reputation of Japanese workers for discipline and loyalty to the firm." They also assert that because assessment by supervisors plays a larger role in the careers of Japanese workers, upward sloping wage profiles are unnecessary in order to deter shirking. However, my focus here is on the wage profiles as a barrier to exit.

27 Tachibanaki and Taki (1990) find in Japanese data that those who have moved to bigger firms receive higher wages while those who have moved to smaller firms decrease their wages. It is however not clear which of the four stories given below these findings favor. 
because she must cover in part his training costs. If it is true that Japanese firms invest in specific training more than Western firms, then this story explains lower labor turnover in Japan. The problem is that it is not clear whether there in fact exist substantial differences in necessary skills among large firms, for example, in the same industry segment.

Second, there may be collusion among firms. Aoki (1988) asserts that "Japanese firms, particularly large and established ones, have bound themselves to an implicit code of not hiring former employees of other firms, particularly skilled ones..." (p. 83). They could punish those who deviate from that code and are detected, by reverting to fierce competition for hiring workers. The question is what enable large Japanese firms to sustain collusion more easily than Western firms.

The third possible reason is that hiring new employees at high hierarchical ranks may have negative effects on existing employees' motivation: The number of promotions available for the junior may be reduced, or obtaining a skilled worker from outside may send some negative signal to insiders concerning their capabilities. This story is pursued more in the next section in association with slow promotion patterns in Japan.

Fourth, firms may infer that a job changer is of low ability or "bad" type. Gibbons and Katz (1989) present a model in which the current employer has better information about worker ability and the market infers that job changers are of low ability. In MacLeod and Malcomson's (1988) model of promotion, which is discussed more in the next section, it is assumed that the market cannot tell whether a worker who has left a firm was fired or voluntarily quit. They can however show that there exists a sequential equilibrium in which the market believes that the final rank of the worker at the previous firm is too high in terms of his ability. A job changer may have difficulty in finding a job even if the market knows that he has separated voluntarily, because he is viewed as a bad-type worker, i.e., who tends to move again.

\section{Promotions and Pay Attached to Ranks}

Promotions in this paper are defined as pay increases that result from moving up to higher vertical or horizontal ranks as defined in Section 2. In other words, pay is primarily attached to a finite number of grades or hierarchical job titles, not to individuals. This implies that

substantial part of information concerning individuals is not used immediately for rewarding 
them: two workers with moderately different performance histories receive approximately equal salaries (via assignment to the same rank). The discussion in Section 4 is relevant. There I explained several perverse incentive effects of using detailed individual performance information for rewarding workers without delay. Some of the arguments are extended to explain speed of promotions in this section.

Note that promotions to upper hierarchical ranks serve a purpose other than providing incentives: better matching of individuals to tasks (here including hierarchical titles) via learning of their ability. More information is accumulated over time about workers' potential ability and characteristics, and their productivity increases via improvement in job matching. Pay not attached to individuals is again a puzzle from the viewpoint of this second purpose because it does not fully use workers' productive skills or information concerning their ability. ${ }^{28}$

In the rest of this section, I present theories of promotions and their implications on the distinct characteristics in the Japanese firm, wide career and slow promotions. First, I focus on the learning aspect of promotions and argue that pure learning models cannot explain slow promotions in the Japanese firm. Next I consider the theory of rank-order tournaments, which focuses on promotion as a pure incentive device, and then consider interactions between these two facets.

\subsection{Promotion as a Learning Device}

In this section, I abstract away incentive problems to focus on the learning aspect. I assume that each worker's ability is initially unknown to firms as well as to himself. The current employer, by observing some performance measures such as merit ratings, accumulates information concerning the worker's true ability. The average productivity of the worker then increases as more information is accumulated, via reassignment to various jobs including

28 The theory of human capital also suggests pay attached to individuals. Williamson et al. (1975) offer one explanation of pay attached to particular jobs (not ranks) within the framework of human capital theory. Their argument hinges on the assumption that a worker accumulates specialized skills and information about his job, and he can have monopoly power against the employer. This explanation appears persuasive when applied to production workers in the unionized Western firm where a strict one wage rate per job is a rule. However, it has problems as an explanation of the Japanese practice. First, Japanese workers are less likely to obtain monopoly positions concerning their jobs, because of their wider careers: it is much less costly to replace a worker by somebody else in the same firm in Japan than in the West, given the differences in organization structures. Second, the use of subjective merit assessment for production workers in Japan is hard to explain under this theory. 
hierarchical titles. (The discussion in this section is thus concerning vertical ranks.) For a while suppose that potential employers in the outside labor market can also observe the same performance measures as the current employer does. Then in each period, the worker is assigned to the position best suited to him based on the market belief on his ability in that period, and is paid the expected value of his marginal product at that position. Because the risk-averse worker dislikes fluctuation of his earnings, the firm may instead offer a long-term contract in order to insure him against uncontrollable risk: Then no demotion or pay cut occurs, while the worker's wage increases often with promotion to higher ranks, only when his previous performance was so good that the updated belief on his ability increases his expected productivity sufficiently and consequently potential employers offer him higher wages to bid him away (see Harris and Holmstrom (1982)).

Note that in the case of symmetric information discussed above, pay is attached to individuals: workers who are assigned to the same rank, but have different performance history, are paid different wages at the same position. This conclusion is however sensitive to the assumption that the performance measures of the worker are observable to the potential employers as well as the current firm: It is often the case that the current employer can have better information about her employees than the others, e.g., because the latter cannot observe the results of merit ratings. On the other hand, it is likely that the outside firms can observe employees' hierarchical ranks and compensation offered by the current employer (e.g., an employee can communicate his title and pay in a verifiable way while it is difficult for him to convince them of his performance in the current firm), and use them as an imperfect signal about ability. Waldman (1984) analyzes such a case and shows that pay attached to ranks arises as an optimal structure.

To see this, suppose for simplicity that there are two periods and two ranks, rank 1 and rank 2. Rank 1 is the "port of entry" to which all the new employees are assigned at the beginning of period 1. At the end of period 1, some performance measure of the employee becomes available, and for simplicity, it reveals his true ability perfectly. If his ability is sufficiently high, he is more productive at rank 2 than at rank 1 . However, the current firm must consider the fact that the market can, by observing the promotion, infer that he is sufficiently able. Firms in the market then attempt to bid him away from the current employer, and she, in order to retain him, requires paying compensation compatible to the 
offers by them. Because the outside offers are only contingent on job assignment (rank 1 or 2), there is no reason for the current employer to use superior information about ability for compensation schemes.

Two important results arise from his model. First, there are a fewer promotions than would be optimal if ability information were known to the market as well. The intuition is that because of the discontinuous jump in pay upon promotion, it is too costly to promote those who are only a little more productive at rank 2 than at rank 1 . Second, as the level of firm-specific human capital increases, this inefficient assignment diminishes, because the efficient assignment becomes more valuable to the current firm.

These results also have important implications on the speed of promotions when the model is extended to the case of more than two periods. Bernhardt (1989) and Waldman (1990) show that promotions are delayed relative to the efficient assignment under symmetric information, and that this delay is negatively related to the proportion of skills that are firm-specific. This result, however, is not consistent with empirical evidence: Specific training is more important in the Japanese firm and general training is more important in American firms (Hashimoto and Raisian, 1985, 1989; Mincer and Higuchi, 1988), while promotions are more delayed in the Japanese firm. The problem of the model, when it is applied to the Japanese management practices, appears to be the assumption of the competitive labor market. If the market is noncompetitive, then the current employer has no incentive to conceal information concerning worker ability, and hence she assigns workers efficiently, resulting in no delay in promotions. Competition among divisions within a firm could mimic the competition in the external labor market, but casual observation does not reveal such competition as a typical practice in the Japanese firm.

\subsection{Promotion Lottery as an Incentive Device}

I next focus on promotions as an incentive scheme. Lazear and Rosen (1981) view salaries as prizes of promotion lotteries and grades as names for prizes. Consider the standard principal-agent model in which several risk-averse workers exert unobservable effort which along with uncontrollable factors determines individual performance. The workers with best performance among them, whose proportion is specified by the contract, are promoted to a 
higher rank with a higher pay (winning prize) fixed in advance. ${ }^{29}$ This contest works as a strong motivator. Note that the workers' abilities are assumed to be common knowledge, and hence we assume away the learning aspect of promotions.

There are three oft-argued reasons why this rank-order tournament scheme may be preferred by the firm. First, it only requires much coarser information of ordinal ranking among workers' performance than cardinal performance measures, and hence its monitoring costs will be smaller. Second, workers' earnings are less affected by uncontrollable noise because their performance ranking is insensitive to common random factors. For example, if the performance of each worker depends on his effort, his machine condition, and the production system of the factory the last of which is uncontrollable and common to all the workers, the last two factors are simply a noise to him, and his pay should not fluctuate contingent on them. While the last common noise factor affects his absolute performance, it does not affect his relative performance. And his ranking among the workers is one example of his relative performance, which filters out the common uncontrollable factor. Note however that this is not a strong reason to choose pay attached to grades than to individuals because the employer could use more elaborated relative performance measures, such as bonuses contingent on the performance of a worker relative to the mean performance among the workers (Holmström, 1982).

Third, the effectiveness of the rank-order tournament scheme is not affected by the subtle condition of whether or not individual performance measures are verifiable (Carmichael, 1983; Malcomson, 1984). If they are not verifiable and hence labor contracts contingent on those measures are not enforceable explicitly, the firm has incentives to renege on what is specified in the contracts: For example, the firm may not raise wages upon observation of good performance, as is specified by the contract, by reporting that performance was not good enough. However, under tournament schemes, the firm has nothing to gain by being dishonest: misreporting a worker's performance being bad when it is actually good simply increases the probability that the other workers win the competition. For this argument to work, the prize must be attached to a hierarchical title which must be filled, or when it is attached to a pay grade, the proportion of workers to be promoted there must be verifiable. These conditions seem easier to satisfy than verifiability of performance measures.

${ }^{29}$ If one assumes that there are "many" employees (a continuum of them), then specifying the proportion to be promoted is equivalent to specifying a threshold level of absolute performance. 
Of course, repeated interaction and reputation can make contracts contingent on unverifiable measures self-enforcing. Such implicit contracts are costly, however, because the firm must earn a surplus by abiding by implicit agreement with workers (MacLeod and Malcomson, 1989). Since the rank-order tournament schemes do not require such a surplus, they have the advantage over pay attached to individuals in the long run.

Problems of the rank-order tournaments: Because the rank-order tournament scheme is but one special form of pay for performance, it is subject to the same problems as discussed in Section 4: fixed costs of risk sharing, danger of tying pay with specific objective measures (including influence costs), and, in particular, perverse effects of merit ratings. Several practices observed in the Japanese firm can be interpreted as ways to mitigate the problems associated with subjective merit ratings. Aoki (1988) observes rotation of both supervisors and subordinates in the Japanese firm. Yoshino (1968) finds that in the Japanese firm "one is rewarded for his competence only after he proves his ability to the satisfaction of everyone concerned." (p. 237, emphasis added.) These organizational responses to the vertical collusion problem naturally lead to the distinct management characteristics in Japan, wide career and slow promotions. Another way to alleviate the problems is to introduce some exogenous criteria such as seniority in promotion decisions, again compatible with the Japanese management practice.

There are some extra costs of tournaments themselves. First, workers who compete for higher positions have no incentive to cooperate. Under tournaments, each worker can increase his winning probability by engaging in "sabotage," reducing performance of his competitors (Lazear, 1988; Itoh, 1991b). Thus, if cooperation among workers is critical as in work organization of the Japanese firm, those who compete for promotions should be separated. Second, contestants have incentives to collude to choose lower effort levels. Thus, they should be again separated or their tasks should be designed so as to prevent them from mutually monitoring their effort, if the firm would like to encourage workers to cooperate as a work group where mutual monitoring and sanctioning enforce their coordinated effort: ${ }^{30}$ In the Japanese firm, employees in the same category in terms of the year of graduation from collage are subject to the same promotion process. Although I know no data, extensive rotations enable them to work in various departments, regional offices, or factories, and, as a result, there is a small

30 The conditions for the firm to prefer doing so are obtained in Holmstrom and Milgrom (1990a), Itoh (1990), and Ramakrishnan and Thakor (1991). 
chance that they work together in the same place, in particular, in large firms. Such a practice will make it possible for the Japanese firm to attain effective cooperation and competition simultaneously.

Third, incentives for those who have lost contests are absent under tournament schemes. Consider a sequence of elimination tournaments in which winners of a tournament proceed to the next tournaments, in order to attain higher positions, while losers are completely eliminated from competition. Competition for higher ranks in hierarchical organizations appears to be well represented by such a sequence of elimination tournaments (Hanada, 1989; Rosenbaum, 1979). ${ }^{31}$ If the firm wants the losers to continue to exert high effort in the rest of their career, then it may be in the interest of the firm to reduce the speed of promotions, in order to keep effort incentives of all the members high, by increasing the proportion of workers to be promoted in their early career.

Note that the slow promotion of this sort has costs as well. First, delay in promotion will increase costs of misassignment of able employees to lower-level jobs. Second, talented employees may quit to receive higher compensation elsewhere. Third, if workers can have control over riskiness of their decision making (e.g., they choose risky projects), their choice may be biased, from the firm's viewpoint, against risky actions too much under elimination tournaments with many winners in early rounds. It may therefore be in the interest of the firm not to slow promotions but to change the structure of elimination tournaments so that early losers can be given second chances to catch up with early winners later in their career. This argument is also found in Hanada (1989).

The optimal speed of promotions will be determined by the tradeoff between the benefits and the costs mentioned above. The argument here predicts slower promotions in the Japanese firm because mid-career separation of able workers seems more costly in Japan, and because the incentives of the losers seem particularly important for Japanese type work organization in which much responsibility is delegated to lower levels of hierarchy.

\subsection{Interaction of Learning and Incentives}

If the incentive effects of promotions are important in the Japanese firm, the results from the pure learning model of promotions in Section 6.1, which are not consistent with the

\footnotetext{
31 See Rosen (1986) for a model of elimination tournaments.
} 
observation of the Japanese practices, may be due to this lack of incentive problems there. I here present several recent studies of promotions that incorporate both learning and incentive facets into rigorous models.

Prendergast (1990a) introduces into a learning model workers' incentives to collect costly firm-specific skills. Only the current employer (not workers) can learn about their abilities, and the issue is whether or not she reveals ability information to workers before training. She can do so credibly by promoting and giving pay raise to only workers with sufficiently high ability. Some of the other workers are then discouraged to collect skills. This case is interpreted as the American mode of career development. Alternatively, the employer can conceal ability information from workers by offering the same terms to all of them. All the workers are then motivated to collect skills. This second case is the Japanese mode of slow promotions.

He shows that without competitive external labor markets, the Japanese mode is preferred to the American mode if the returns to specific training are sufficiently high, because the former alleviates the firm's incentive to exaggerate workers' talent to induce them to collect skills. This result seems compatible with the observation that specific skills are more important in Japanese work organization. He also shows that if the external labor market is competitive, the advantage of the Japanese system under no labor market disappears because bids from the market reveal ability information to workers. ${ }^{32}$

Prendergast (1990c) considers career concerns, which arise in the learning model when the moral hazard problem is present, i.e., workers can exert unobservable effort to influence the beliefs on their ability held by the internal or external labor market. Two workers with symmetric uncertainty about each worker's ability joins a firm. The employer observes some signal about each worker's ability, which fact determines the "leader" and the "follower." She then trains two workers through on-the-job training while the workers exert effort, and additional signals on ability become available. Based on the updated beliefs on ability and the returns to training, one of them is promoted to a higher rank with higher pay.

He shows that when no competitive labor market exists, the firm designs on-the-job

32 The current firm's incentive to conceal information from the market will not preclude information leakage perfectly. On the other hand, if the American system is optimal with no labor market (e.g., because specific training is too costly), the bids from the labor market do not have detrimental effects, while the incentive to conceal appears. The net result may be slower promotions with the competitive labor market than without, for the reason discussed in Section 6.1. 
training such that the leader is handicapped: the follower is given more training so that their race is "tight." This case seems closer to the Japanese practice that everyone is given a chance to receive training and to demonstrate its potential capability. On the other hand, when the labor market is competitive, the leader is given more training, which result Prendergast interprets as "star treatment" typical in the American firm.

Note that in both papers Prendergast takes the competitiveness of the external labor market as an exogenous factor. However, the lack of the competitive labor market may arise endogenously from his models (see Section 5.2 for relevant discussion). Suppose that in Prendergast (1990a), the Japanese mode of slow promotion is optimal with no labor market, and that offers by a firm to outsiders are observable to its own employees. Then such offers before training reveal ability information to own employees, which discourages them to collect skills. It may therefore be in the interest of firms not to offer outsiders high job ranks when the Japanese type pooling scheme is optimal in the absence of the competitive labor market. Similarly, in Prendergast (1990c), if the firm attempts to hire a leader away from other firms, anticipating such a possibility, the employees reduce their effort because the marginal return to effort decreases as the probability of winning a high rank is reduced.

The implication from this argument is the same as that given at the beginning of Section 5: The Western management and the Japanese management may represent two different equilibria one of which has a competitive labor market and the other has a non-competitive one.

Another model worth mentioning is the self-selection model by MacLeod and Malcomson (1988) which Aoki (1988) uses to explain economic rationale of wages attached to pay grades in the Japanese firm. They consider the adverse-selection case where the ability of each worker is his private information. Because performance measures are not verifiable, self-enforcing contracts are of termination type: if the performance of a worker is unsatisfactory, he is fired, while given that his performance is satisfactory, his pay is independent of his current performance level. They show that the equilibrium rank hierarchy has a finite number of pay grades, despite a continuum of possible ability levels. The intuition is that in the equilibrium they consider, when a worker separates from the employer, the market infers that he was assigned to a pay grade too high in terms of his true ability. Thus, in the new firm, he is assigned to a grade just below his previous one. The number of grades must therefore be finite 
and the utility difference between grades must be discrete, in order to make shirking and the resulting separation costly. In equilibrium, each worker self-selects the grade appropriate to his ability, and hence no separation occurs. From the firm's point of view, self-selection is optimally attained by first assigning all the workers to the lowest grade, and promoting them one grade each period if his performance satisfies the promotion criteria, until each of them reaches his optimal grade. The firm makes positive profits from each worker before he reaches his grade.

Their model explains the optimality of promotion schemes, but does not provide clear insights on the speed of promotions. ${ }^{33}$ More seriously, the use of termination-type contracts in Japan appears to be limited, because it is costly for the firm to fire workers: As I mention in Section 2, the "lifetime" employment policy binds employers both implicitly and explicitly. MacLeod and Malcomson consider contacts of termination type because they are only selfenforcing contracts given that performance measures are not verifiable. Although this story may characterize the equilibrium in labor markets in the West, I conjecture that the Japanese firm, because of the additional constraints, takes another route, using unverifiable performance measures (in particular, subjective merit assessments) by mitigating the verifiability problems by some means.

\subsection{Notes on Seniority as a Promotion Criterion}

Before closing the section, I comment on the question: why seniority is an important determinant of promotions in the Japanese firm. Seniority seems to provide some upper bound on the speed of promotions. However capable a worker is known to be, he has to wait for promotions to high hierarchical ranks until he becomes sufficiently senior (tenure or age). One obvious reason is specific human capital. Even if a worker's potential ability is high, he needs to accumulate specific skills before promoted. A related reason is that the seniority rule

33 One possible explanation comes from the feature of their promotion process that the firm can increase its profits by shirking and delaying promotion. In the equilibrium MacLeod and Malcomson consider, the market beliefs are optimistic enough to enable employees to deter such shirking by the employer costlessly by quitting the firm. However, if a worker's cost of mid-career separation is high (e.g., because the market beliefs for the ability of job changers are quite pessimistic), he will prefer staying and accepting delay to separating from the firm, and hence promotion delay may prevail. Alternatively, slow promotion and wide career could arise from their model because the performance measures are often subjective and hence the problems associated with merit ratings are inevitable in their model as well. 
seniority rule enables senior employees to smoothly transfer their skills and information to young employees, as well as to evaluate the latter honestly. Without the rule, the senior would have incentives to reduce promotion prospects of the young. This argument is more relevant in the Japanese firm because of the importance of on-the-job training and merit assessments in its work organization. The similar argument holds for hiring decisions. To provide senior employees with incentives to hire able individuals, the firm must give the senior some guarantee that those capable young employees will not jeopardize their positions. Given the high costs of mid-career separation such a consideration is likely to be more serious in Japan.

\section{Concluding Remarks}

The existing literature on Japanese firms mostly focuses on what-questions: what is different and what is similar in the Japanese management practices? This paper instead focuses on why-questions concerning internal incentives in the Japanese firm from economic perspectives.

There are three main messages in the paper. First, if we take work organization structures of the Japanese firm given, then its reward structures and employment relationships are quite consistent with the insights from the recent literature in economic theories of organizations. More rigorous studies of pay and promotion schemes are required, but the lack of theoretical studies of organization structures appears to be a more serious problem in the theoretical point of view. Successful models could explain simultaneously the distinct features of work organization and employment structures in the Japanese firm, along with market conditions. They would also offer more consistent explanation of the differences between the Japanese firm and the Western firm, e.g., they might characterize the contrast as two different equilibria in the models.

Second, although much comparative empirical evidence on the Japanese management practices is now available, rigorous tests of alternative theories are still absent. It seems to me that most of those who study Japanese human resource management have exclusively focused on the theory of firm-specific human capital, regarding incentive issues as irrelevant in the Japanese firm, for some exogenous reasons. I think that specific skills are important determinants of the Japanese practices, but as I argue in the paper, they are not likely to be 
the whole story: Some empirical observations can be explained in a more consistent way by incentive theory. Our further understanding on the Japanese human resource management practices will improve substantially when we can obtain micro personnel data from Japanese firms and test several theories.

Third, many distinct features of the Japanese human resource management, along with other features of organization and market structures, are likely to constitute a "system": they are closely interrelated and there could not exist one aspect of the Japanese system without all the other. 


\section{REFERENCES}

AokI, M. (1986): "Horizontal vs. Vertical Information Structure of the Firm," American Economic Review, 76, pp. 971-83.

(1988): Information, Incentives, and Bargaining in the Japanese Economy. Cambridge: Cambridge University Press.

(1990): "The Participatory Generation of Information Rents and the Theory of the Firm," in M. Aoki, B. Gustafsson, and O. E. Williamson, eds., The Firm as a Nexus of Treaties. London: Sage Publication.

Baker, G. P., M. C. Jensen, and K. J. Murphy (1988): "Compensation and Incentives: Practice vs. Theory," Journal of Finance, 43, pp. 593-616.

Becker, G. S. (1975): Human Capital: A Theoretical and Empirical Analysis, with Special Reference to Education. Second Edition. Chicago: University of Chicago Press.

Bernhardt, D. (1989): "Skill Profiles, Observability and Firm Hierarchies: A Theory of Promotion and Compensation," Discussion Paper \#764, Department of Economics, Queen's University.

Carmichael, L. (1983): "Firm-Specific Human Capital and Promotion Ladders," Bell Journal of Economics, 14, pp. 251-58.

Cole, R. E. (1989): Strategies for Learning: Small-Group Activities in American, Japanese, and Swedish Industry. Berkeley: University of California Press.

EDWARDS, R. (1979): Contested Terrain: The Transformation of the Workplace in the Twentieth Century. New York: Basic Books.

Forbes, J. B. (1987): "Early Intraorganizational Mobility: Patterns and Influences," Academy of Management Journal, 30, pp. 110-25.

Freeman, R. B. And M. L. Weitzman (1987): "Bonuses and Employment in Japan," Journal of the Japanese and International Economies, 1, pp. 168-94.

Fujimura, H. (1989): "Seiseki Satei no Kokusai Hikaku" (International Comparison of Merit Ratings), Nihon Rōdō Kyōkai Zasshi, 362, pp. 26-37.

Gibbons, R. S. and L. F. Katz (1989): "Layoffs and Lemons," Working Paper \#531, MiT.

Gibbons, R. S. And K. J. Murphy (1990): "Optimal Incentive Contracts in the Presence of Career Concerns: Theory and Evidence," Working Paper \#563, MIT.

HAnadA, M. (1989): "The Principle of Competition in Japan's Personnel System," Japanese Economic Studies, 17, pp. 3-22.

Harris, M. And B. Holmstrom (1982): "A Theory of Wage Dynamics," Review of Economic Studies, 49, pp. 315-33.

HarT, O. and B. Holmström (1987): "The Theory of Contracts," In T. F. Bewley, ed., Advances in Economic Theory, Fifth World Congress, Cambridge: Cambridge University Press, pp. 71-155. 
Hashimoto, M. (1979): "Bonus Payments, On-The-Job Training, and Lifetime Employment in Japan," Journal of Political Economy, 87, pp. 1086-104.

(1981): "Firm-Specific Human Capital as a Shared Investment," American Economic Review, 71, pp. 475-82.

(1990): "Employment and Wage Systems in Japan and Their Implications for Productivity," in A. S. Blinder, ed., Paying for Productivity: A Look at the Evidence. Washington, D.C.: The Brookings Institution.

Hashimoto, M. and J. Raisian (1985): "Employment Tenure and Earnings Profiles in Japan and the United States," American Economic Review, 75, pp. 721-35.

(1989): "Investments in Employer-Employee Attachments by Japanese and U.S. Workers in Firms of Varying Size," Journal of the Japanese and International Economies, 3, pp. 31-48.

Holmström, B. (1982): "Moral Hazard in Teams," Bell Journal of Economics, 13, pp. 32440.

Holmstrom, B. And P. Milgrom (1990a): "Regulating Trade among Agents," Journal of Institutional and Theoretical Economics, 146, pp. 85-105.

(1990b): "Multi-Task Principal-Agent Analyses: Incentive Contracts, Asset Ownership and Job Design," mimeo. Yale School of Organization and Management.

Hutchens, R. M. (1987): "A Test of Lazear's Theory of Delayed Payment Contracts," Journal of Labor Economics, 5, pp. S153-70.

IshidA, M. (1990): Chingin no Shakai Kagaku: Nippon to Igirisu (Social Science of Wages: Japan and Britain). Tokyo: Chūō Keizaisha.

Iтон, H. (1987): "Information Processing Capacities of the Firm," Journal of the Japanese and International Economies, 1, pp. 299-326.

(1988): "Information Structures, Task Structures, and Coordination Systems," Working Paper \#4, Faculty of Economics, Kyoto University.

(1990): "Coalitions, Incentives, and Risk Sharing," Working Paper \#10, Faculty of Economics, Kyoto University, December.

- (1991a): "Incentives to Help in Multi-Agent Situations," Econometrica, 59.

(1991b): "Cooperation in Hierarchical Organizations: An Incentive Perspective," Working Paper \#12, Faculty of Economics, Kyoto University, March.

Kagono, T., I. Nonaka, K. Sakakibara and A. Okumura (1985): Strategic vs. Evolutionary Management: A U.S.-Japan Comparison of Strategy and Organization. Amsterdam: North-Holland.

Kalleberg, A. L. and J. R. Lincoln (1988): "The Structure of Earnings Inequality in the United States and Japan," American Journal of Sociology, Supplement to 94, pp. S121-53.

KoIKe, K. (1988): Understanding Industrial Relations in Modern Japan. Macmillan Press. (1991): Daisotsu Howaito Karā no Jinzai Kaihatsu (Human Resource Development of Collage-Graduate White-Collar Workers). Tokyo: Tōyō Keizai Shinpō Sha. 
Krueger, A. B. (1991): "Ownership, Agency, and Wages: An Examination of Franchising in the Fast Food Industry," Quarterly Journal of Economics, 106, pp. 75-101.

LAfFont, J.-J. (1990): "Analysis of Hidden Gaming in a Three-Level Hierarchy," Journal of Law, Economics, and Organization, 6, pp. 301-24.

LAZEAR, E. P. (1979): "Why Is There Mandatory Retirement?" Journal of Political Economy, 87, pp. 1261-84.

(1981): "Agency, Earnings Profiles, Productivity, and Hours Restrictions," American Economic Review, 71, pp. 606-20. pp. $561-80$.

(1989): "Pay Equality and Industrial Politics," Journal of Political Economy, 97,

Lazear, E. P. and S. Rosen (1981): "Rank-Order Tournaments as Optimal Labor Contracts," Journal of Political Economy, 89, pp. 841-64.

Lazear, E. P. And R. L. Moore (1984): "Incentives, Productivity, and Labor Contracts," Quarterly Journal of Economics, 99, pp. 275-95.

Lincoln, J. R., M. Hanada, And K. McBride (1986): "Organizational Structures in Japanese and U.S. Manufacturing," Administrative Science Quarterly, 31, pp. 338-64.

Lincoln, J. R. and A. L. Kalleberg (1990): Culture, Control, and Commitment: A Study of Work Organization and Work Attitudes in the United States and Japan. Cambridge: Cambridge University Press.

Lincoln, J. R. And K. MCBRIDE (1987): "Japanese Industrial Organization in Comparative Perspective," Annual Review of Sociology; 13, pp. 289-312.

MacLeod, W. B. and J. M. Malcomson (1988): "Reputation and Hierarchy in Dynamic Models of Employment," Journal of Political Economy, 96, pp. 832-54.

(1989): "Implicit Contracts, Incentive Compatibility, and Involuntary Unemployment," Econometrica, 57, pp. 447-80.

Malcomson, J. M. (1984): "Work Incentives, Hierarchy, and Internal Labor Markets," Journal of Political Economy, 92, pp. 486-507.

Milgrom, P. R. (1988): "Employment Contracts, Influence Activities and Efficient Organization Design," Journal of Political Economy, 96, pp. 42-60.

Milgrom, P. And J. Roberts (1988): "An Economic Approach to Influence Activities in Organizations," American Journal of Sociology, Supplement to 94, pp. S154-79.

Mincer, J. AND Y. Higuchi (1988): "Wage Structures and Labor Turnover in the United States and Japan," Journal of the Japanese and International Economies, 2, pp. 97-133.

Monden, Y. (1983): Toyota Production System: Practical Approach to Production Management. Norcross: Industrial Engineering and Management Press.

MurPhy, K. J. (1986): "Incentives, Learning, and Compensation: A theoretical and Empirical Investigation of Managerial Labor Contracts," Rand Journal of Economics, 17, pp. 59-76.

OECD (1984): OECD Employment Outlook. 
Онаsнi, I. (1989): "On the Determinants of Bonuses and Basic Wages in Large Japanese Firms," Journal of the Japanese and International Economies, 3, pp. 451-79.

Okuno, M. (1984): "Corporate Loyalty and Bonus Payments: An Analysis of Work Incentives in Japan," in M. Aoki, ed., The Economic Analysis of the Japanese Firm. Amsterdam: North-Holland.

Okuno-Fujiwara, M. (1987): "Monitoring Cost, Agency Relationship, and Equilibrium Modes of Labor Contract," Journal of the Japanese and International Economies, 1, pp. $147-67$.

Ono, A. (1989): Nihonteki Koyō Kankō to Rōdō Shijōo (Japanese Employment Practices and Labor Markets). Tokyo: Tōyō Keizai Shinpō Sha.

Prendergast, C. (1990a): "Career Development and the Signaling Effect of Wages and Promotion," mimeo. Nuffield College, Oxford.

(1990b): "A Theory of Worker Responsibility for Japan and the United States," mimeo. Nuffield College, Oxford.

- (1990c): "The Economics of Star Treatment," mimeo. University of Chicago.

Pucik, V. (1985): "Promotion Patterns in a Japanese Trading Company," Columbia Journal of World Business, 20.

Ramakrishnan, R. T. S. And A. V. Thakor (1991): "Cooperation versus Competition in Agency," forthcoming in Journal of Law, Economics, and Organization.

Rosen, S. (1986): "Prizes and Incentives in Elimination Tournaments," American Economic Review, 76, pp. 701-15.

Rosenbaum, J. E. (1979): "Tournament Mobility: Career Patterns in a Corporation," Administrative Science Quarterly, 24, pp. 220-41.

Shapiro, C. And J. E. Stiglitz (1984): "Equilibrium Unemployment as a Worker Discipline Device," American Economic Review, 74, pp. 433-44.

Stiglitz, J. E. (1975): "Incentives, Risk, and Information: Notes towards a Theory of Hierarchy," Bell Journal of Economics, 6, pp. 552-79.

Tachibanaki, T. (1987): "The Determination of the Promotion Process in Organizations and of Earnings Differentials," Journal of Economic Behavior and Organization, 8, pp. 603-16. (1988): "Education, Occupation, Hierarchy and Earnings," Economics of Education Review, 7, pp. 221-29.

TAChibanaki, T. And A. TAKi (1990): "Wage Determination in Japan: A Theoretical and Empirical Investigation," in H. Konig, ed., Economics of Wage Determination. Berlin: Springer-Verlag.

Tirole, J. (1986): "Hierarchies and Bureaucracies: On the Role of Collusion in Organizations," Journal of Law, Economics, and Organization, 2, pp. 181-214.

Trevor, M. (1983): Japan's Reluctant Multinationals: Japanese Management at Home and Abroad. London: Frances Pinter. 
Tsuchida, M. (1989): "Nihonteki Koyō Kankō to Rōdō Keiyaku" (Japanese Employment Practices and Labor Contracts), Nihon Rōdōhō Gakkaishi, 73, pp. 31-70.

Waldman, M. (1984): "Job Assignments, Signalling, and Efficiency," Rand Journal of Economics, 15, pp. 255-67.

(1990): "A Signalling Explanation for Seniority Based Promotions and Other Labor Market Puzzles," mimeo. UCLA.

WeIsS, A. (1984): "Simple Truths of Japanese Manufacturing," Harvard Business Review, 62, pp. 119-25.

(1988): "Incentives and Worker Behavior: Some Evidence," in H. R. Nalbantian, ed., Incentives, Cooperation, and Risk Sharing. Savage: Rowman and Littlefield.

WhitTaker, D. H. (1990): Managing Innovation: A Study of British and Japanese Factories. Cambridge: Cambridge University Press.

Williamson, O. E., M. L. Wachter, and J. E. Harris (1975): "Understanding the Employment Relation: The Analysis of Idiosyncratic Exchange," Bell Journal of Economics, 6 , pp. 250-80.

Yoshino, M. Y. (1968): Japan's Managerial System: Tradition and Innovation. Cambridge: MIT Press. 


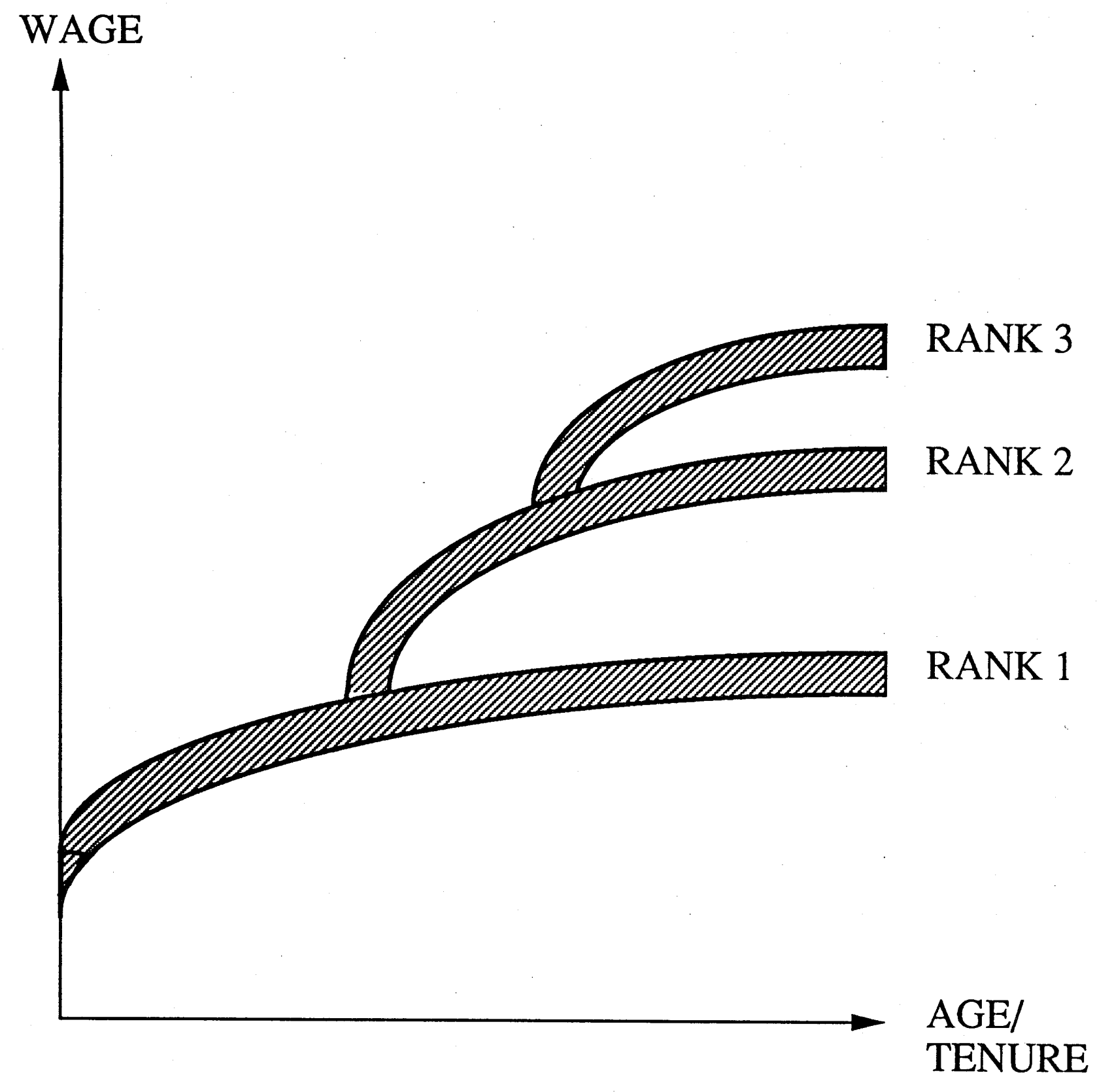

Figure a 